Pesq. Vet. Bras. 35(10):835-841, outubro 2015 DOI: 10.1590/S0100-736X2015001000003

\title{
Biofilm formation by Rhodococcus equi and putative association with macrolide resistance ${ }^{1}$
}

\author{
Letícia T. Gressler ${ }^{2 *}$, Agueda C. de Vargas ${ }^{2}$, Mateus M. da Costa ${ }^{3}$, Fernando Jonas Sutili ${ }^{4}$, Marcelo \\ Schwab $^{2}$, Daniela Isabel B. Pereira ${ }^{5}$, Luís Antonio Sangioni ${ }^{2}$ and Sônia de A. Botton ${ }^{2}$
}

\begin{abstract}
Gressler L.T., Vargas A.C., Costa M.M., Sutili F.., Schwab M., Pereira D.I.B., Sangioni L.A. \& Botton S.A. 2015. Biofilm formation by Rhodococcus equi and putative association with macrolide resistance. Pesquisa Veterinária Brasileira 35(10):835-841. Universidade Federal de Santa Maria, Av. Roraima 1000, Camobi, Santa Maria, RS 97105-900, Brazil. E-mail: sabott20@gmail.com

Rhodococcus equi is a facultative intracellular pathogen, which cause severe pyogranulomatous pneumonia in foals and tuberculosis-like lesions in humans. Its ability to form biofilm was described in strains isolated from chronic diseases associated to treatment failures in humans. This study aimed to verify the biofilm formation by 113 R. equi isolated from equine samples (clinical and fecal) using two different methods (biofilm-culturing with and without additional glucose and epifluorescence microscopy). We also aimed to determine the efficacy of azithromycin, clarithromycin and erythromycin on $R$. equi in established biofilm. We found $80.5 \%(26 / 41)$ and $63 \%(58 / 72)$ biofilm-positive isolates, in fecal and clinical samples, respectively. The additional glucose increased the biofilm formation by $R$. equi fecal samples, but not by clinical samples. The antimicrobials tested herein were not able to eradicate $R$. equi in biofilm even at higher concentrations. This is the first study showing the biofilm formation by $R$. equi isolated from equine samples. Our findings indicate that $R$. equi biofilm-producers may be more resistant to the antimicrobials evaluated. Further studies are warranted to test this hypothesis.
\end{abstract}

INDEX TERMS: Antimicrobial resistance, biofilm, DAPI, macrolides, Rhodococcus equi.

RESUMO.- [Formação de biofilme por Rhodococcus equi e posspivel associação com resistência a macrolídeos.] Rhodococcus equi é um patógeno intracelular facultativo, o qual causa pneumonia piogranulosa severa em potros e lesões semelhantes à tuberculose em humanos. A sua capacidade de formar biofilme foi descrita em cepas humanas, isoladas a partir de doenças crônicas associadas a falhas

\footnotetext{
${ }^{1}$ Received on October 16, 2014.

Accepted for publication on August 24, 2015.

${ }^{2}$ Departamento de Medicina Veterinária Preventiva, Universidade Federal de Santa Maria (UFSM), Av. Roraima 1000, Santa Maria, RS 97105-900, Brazil. *Corresponding author: sabott20@gmail.com

${ }^{3}$ Laboratório de Microbiologia e Imunologia Animal, Universidade Federal do Vale do São Francisco (Univasf), Rodovia BR-407 Km 12, Lote 543, Projeto de Irrigação Nilo Coelho s/n C1, Petrolina, PE 56300-000, Brazil.

${ }^{4}$ Departamento de Fisiologia e Farmacologia, Universidade Federal de Santa Maria (UFSM), Av. Roraima 1000, Santa Maria, RS 97105-900, Brazil.

${ }^{5}$ Laboratório de Micologia, Departamento de Microbiologia e Parasitologia, Instituto de Biologia, Universidade Federal de Pelotas (UFPel), Prédio 18, Sala 14. Campus Universitário Capão do Leão s/n, Capão do Leão, RS 96160-000, Brazil.
}

de tratamento. Este estudo teve como objetivo verificar a formação de biofilme por 113 cepas de R. equi, isoladas a partir de amostras de equinos (clínicas e fecais), utilizando-se dois diferentes métodos (biofilme em cultura - com e sem adição de glicose - e microscopia de epifluorescência). Além disso, buscou-se determinar a eficácia da azitromicina, claritromicina e eritromicina sobre biofilme consolidado de $R$. equi. Verificou-se $80,5 \%$ (26/41) e 63\% dos isolados (58/72) positivos para formação de biofilme, em amostras fecais e clínicas, respectivamente. A adição de glicose amentou a formação de biofilme em amostras fecais, mas não em amostras clínicas. Os antimicrobianos aqui testados não foram capazes de erradicar R. equi em biofilme consolidado, mesmo em concentrações elevadas. Este é o primeiro estudo a demonstrar a formação de biofilme por cepas de R. equi isoladas a partir de amostras de equinos. Os resultados indicam que os isolados de $R$. equi produtores de biofilme podem ser mais resistentes aos antimicrobianos avaliados. Estudos adicionais são necessários para testar essa hipótese. 
TERMOS DE INDEXAÇÃO: Resistência antimicrobiana, biofilme, DAPI, macrolídeos, Rhodococcus equi.

\section{INTRODUCTION}

Rhodococcus equi is a facultative intracellular and telluric pathogen (Prescott 2004). It is also the etiologic agent of equine rhodococcosis, a disease that typically affects 3 -week to 6-month-old foals (Giguère \& Prescott 1997). This bacterium has a worldwide distribution and is frequently widespread in the environment, such as horse-breeding farms (Takai 1997) and public areas, including sand areas in parks (Takai et al. 1996, Fernandes et al. 2013). Furthermore, $R$. equi was described as a causative agent of opportunistic infections, especially in immunocompromised humans (Arlotti et al. 1996). In these patients, the clinical manifestations are similar to those of pulmonary tuberculosis, with prominent fatality rates (Muscatello et al. 2007). Moreover, reports of rhodococcosis infection have increased in immunocompetent patients (Von Bargen \& Haas 2009).

The discovery of virulence plasmids in $R$. equi allowed its classification as virulent, intermediately virulent and avirulent. Virulent isolates have a large plasmid that encodes a cluster of genes encoding proteins associated with virulence, including the virulence-associated protein A (VapA) (Takai et al. 1991). Virtually, all isolates from affected foals contain the VapA, considered a key factor in the rhodococcosis occurrence in these animals (Takai et al. 1996). On the other hand, several points associated with the survival and proliferation of $R$. equi in the environment, as well as in the foal's lungs, still remain unknown (Muscatello et al. 2006). After $R$. equi genomic sequencing some putative virulence factors were described, including genes potentially responsible for extracellular polysaccharides (EPS) synthesis (Letek et al. 2010). Bacteria surrounded by EPS material are known as biofilm-producers, an important convergent survival strategy among the microorganisms (Donlan \& Costerton 2002). Biofilm is considered a phase of bacterial development in which the bacteria change from the planktonic form to the sessile life (O'Toole et al. 2000). The biofilm-forming bacteria can tolerate antimicrobial concentrations up to 1,000 times more than the same bacterial species in their planktonic form (Costerton et al. 1999, Mah \& O'Toole 2001).

Diseases associated with biofilms require novel metho$\mathrm{ds}$ for their prevention and treatment. In this respect, the ability to form biofilm has been evaluated in $R$. equi isolates from humans showing bacteremia after prolonged treatment (Akhrass et al. 2012, Remuzgo-Martínez et al. 2013). The currently therapy of equine rhodococcosis consist of macrolide associated to rifampin, for which there is emergence of resistance (Giguère et al. 2010). Additionally, there is no clear and straightforward antimicrobial protocol that would indicate an adequate treatment for animals infected by the resistant strains (Cisek et al, 2014). Due the above described, this study aimed to verify the biofilm formation by $113 R$. equi isolates from equine samples (clinical and fecal) using three different approaches. We also aimed to determine the efficacy of three macrolide antibiotics on $R$. equi in established biofilm.

\section{MATERIALS AND METHODS}

\section{Bacterial samples}

A total of 113 equine Rhodococcus equi isolates from clinical $(n=41)$ and fecal $(n=72)$ samples were used in this study. The clinical samples were recovered from post-mortem pulmonary and extra pulmonary lesions in horses subsequent to antimicrobial treatment, and the fecal samples were recovered from healthy mares. These samples were obtained from ten horse-breeding farms in the south of Brazil from 1991 to 2009. All samples were characterized as $R$. equi by morpho-dyeing and biochemical testing according to Quinn et al. (1994) and the identification was confirmed genotypically by Monego et al. (2009). R. equi isolates were lyophilized and stored at $-20^{\circ} \mathrm{C}$ until the tests were performed.

\section{Biofilm development}

Biofilm-culturing (BC) assay. This method was chosen because it is considered the gold-standard method for biofilm detection (Mathur et al. 2006). The quantitative determination of biofilm formation was performed by the spectrophotometric method, which measures the total biofilm biomass, including bacterial cells and EPS matrix. This assay was performed as described previously (Merino et al. 2009) with minor modifications. Briefly, $5 \mu \mathrm{L}\left[\approx 10^{8}\right.$ colony forming units (CFU)/mL] of a culture of $R$. equi grown overnight in tryptone soya broth (TSB) medium (Himedia ${ }^{\circledR}$ Laboratories) at $37^{\circ} \mathrm{C}$ were inoculated into 96-wells microtiter plates (Nunclon ${ }^{\circledR}$ Delta) containing $195 \mu \mathrm{L}$ of TSB. After $24 \mathrm{~h}$ of incubation at $37^{\circ} \mathrm{C}$, in static and aerobic conditions, the microtiter plates were washed three times with $200 \mu \mathrm{L}$ of sterile water, dried in an inverted position, and stained with $100 \mu \mathrm{L}$ of $0.25 \%$ crystal violet for $5 \mathrm{~min}$ at room temperature. Following the microtiter plates were rinsed again three times with sterile water and dried. Later, the dye was dissolved in $200 \mu \mathrm{L}$ of ethanol-acetone (80:20), and the absorbance was measured in an ELISA microtiter-plate reader (SpectraMax ${ }^{\circledR}$, Molecular Devices) at 570nm-wavelength. All assays were performed in triplicate and repeated three times. Uninoculated TSB medium was used as a negative control. To ensure the quality of the tests, a reference strain of Staphylococcus aureus ATCC 25923 was used as positive control for biofilm formation (Marques et al. 2007). Absorbance values greater than the negative control were considered positive. The arithmetic mean of the triplicates was calculated.

Biofilm-culturing with additional glucose (BCG) assay. Although $R$. equi is not known to use sugars, fermentation pathways involving the glucose metabolism have recently been proposed according to the available genome (Letek et al. 2010). Given the importance of glucose as substrate for biofilm-producers (Agarwal \& Jain, 2013) we evaluated its influence on biofilm formation by $R$. equi. The method above was employed with additional $0.25 \%$ glucose in the TSB medium and all $R$. equi isolates were retested.

Epifluorescence microscopy (EM) assay. $R$. equi isolates were cultured in TSB medium at $37^{\circ} \mathrm{C}$ during $24 \mathrm{~h}$ in aerobic conditions. An inoculum $(200 \mu \mathrm{L})$ corresponding to $\approx 10^{8} \mathrm{CFU} / \mathrm{mL}$ of each $R$. equi cultures grown overnight under static conditions was distributed in a sterile petri plate $(50 \mathrm{~mm} \times 10 \mathrm{~mm})$ containing a sterile coverslip (18mm x $18 \mathrm{~mm}$ ) and $3.0 \mathrm{~mL}$ of TSB. All plates were incubated under the same conditions as described above. Next, the coverslips were then heat-fixed and stained with $10 \mu \mathrm{L}$ of 4,6-diamino-2-phenylindole (DAPI; Sigma $\left.{ }^{\circledR}\right)(2 \mathrm{mg} / \mathrm{mL})$ and attached to slides. The biofilm formation on the coverslips was observed with an epifluorescence microscope at 100x lens $(395 \mathrm{~nm}$ of absorption and 440nm of emission). Biofilm-forming bacteria were observed in conjunction with the EPS matrix. Bacteria were 
considered biofilm-negative when they presented no EPS matrix around the stained cells. This technique was adapted from Feazel et al. (2009).

\section{Antimicrobial activity}

Planktonic antimicrobial susceptibility testing. This test was performed to calculate the antimicrobial concentration to be used in the antimicrobial tests with R. equi established biofilm. Eight $R$. equi isolates (from clinical and fecal samples), positive in all biofilm formation tests described above (selection criteria), were selected to carry out the antimicrobial susceptibility testing. The minimum inhibitory concentration (MIC) tests were performed in Müeller-Hinton broth (MHB) medium (Himedia ${ }^{\circledR}$ Laboratories) using the microdilution method in accordance with the guidelines of the Clinical and Laboratory Standards Institute (CLSI 2013). All microorganisms were cultivated in $\mathrm{MHB}$ for $24 \mathrm{~h}$ at $37^{\circ} \mathrm{C}$. For each microorganism, an inoculum suspension was prepared in $0.9 \%$ saline, adjusted to the turbidity of 0.5 on the McFarland' scale, and absorbance readings were performed in a spectrophotometer at $600 \mathrm{~nm}$-wavelength. These suspensions were diluted in MHB to approximately $1 \times 10^{5} \mathrm{CFU} / \mathrm{mL}$. The antimicrobials tested were azithromycin (AZT), clarithromycin (CLAR) and erythromycin (ERY), macrolides commonly used in the treatment of equine rhodococcosis. The antibiotic concentrations tested were: $0.0625,0.125$, $0.25,0.5,1,2,4,8,16,32,64$, and $128 \mu \mathrm{g} / \mathrm{mL}$. The reference strain Staphylococcus aureus ATCC 29213 was used for assay validation. R. equi ATCC 33701, known to be susceptible to azithromycin, clarithromycin and erythromycin, was also used as control (Giguère et al. 2010). The MIC was defined as the lowest concentration of antimicrobials that inhibited the visible growth ( $\geq 99 \%)$ of $R$. equi after incubation. $R$. equi isolates were categorized as susceptible $(\leq 2 \mu \mathrm{g} / \mathrm{mL}$ - azithromycin and clarithromycin, and $\leq 0.5 \mu \mathrm{g} /$ $\mathrm{mL}$ - erythromycin) or resistant $(\geq 8 \mu \mathrm{g} / \mathrm{mL}$ - azithromycin, clarithromycin and erythromycin) in accordance with CLSI (2008 and 2009). Additionally, isolates with MIC values between the aforementioned concentrations were categorized as intermediate susceptibility.

Biofilm antimicrobial susceptibility testing. This test was performed verfiy the effect of the same antimicrobials used in the test described in 2.3.1 item against the same $R$. equi isolates, but in established biofilms. This technique was adapted from Cerca et al. (2005). Briefly, overnight $R$. equi cultures grown under static conditions were inoculated into TSB medium in 1:100 dilution in 24-well cell culture plates (Falcon). These plates were incubated at $37^{\circ} \mathrm{C}$ during $24 \mathrm{~h}$. Afterward, all wells were rinsed three times with phosphate-buffered saline (PBS), without disturbing the adherent film, and $1 \mathrm{~mL}$ of the solution containing antimicrobials $(8 \mu \mathrm{g} / \mathrm{mL})$ diluted in TSB medium or only TSB medium (control) was added to each well. The plates were incubated at $37^{\circ} \mathrm{C}$ for $24 \mathrm{~h}$. The solutions were aspirated and all wells were rinsed three times with PBS and the biofilm were disrupted with a solution of Triton X-100 1\% in PBS for 20 min. The viable cells were determined by performing 10 -fold serial dilutions of this suspension and plating $100 \mu \mathrm{L}$ of the dilutions in triplicate on tryptone soya agar (TSA) plates that were then incubated for $24 \mathrm{~h}$ at $37^{\circ} \mathrm{C}$. This experiment was repeated two times, with individual samples evaluated in triplicate.

\section{Statistical analysis}

The Kruskal-Wallis test was used to calculate the difference in the frequency of biofilm formation among the methods. The correlation between the assays were performed by Spearman correlation analysis. The difference in the CFU counts among the groups was compared by one-way Analysis of Variance (ANOVA) followed by the Tukey's test. The minimum significance level considered was $P<0.05$. The data were analyzed by SAS statistical software.

\section{RESULTS \\ Detection of biofilm formation}

The results may be verified in Table 1, briefly, biofilm formation was observed in 46\% (52/113), 56\% (63/113)

Table 1. Total number and relative frequency of Rhodococcus equi biofilm-producers according the sample source and assay employed

\begin{tabular}{|c|c|c|c|c|}
\hline \multirow{2}{*}{$\begin{array}{c}\text { Samples } \\
\text { source }\end{array}$} & \multicolumn{4}{|c|}{ Number of biofilm-producers isolates (\%) } \\
\hline & Biofilm-cult & $\begin{array}{l}\text { Biofilm-culturing } \\
+ \text { Glucose }\end{array}$ & $\begin{array}{c}\text { Epifluorescence } \\
\text { microscopy }\end{array}$ & Cumula \\
\hline Clir & $19 / 41(46$ & $17 / 4$ & $16 / 4$ & $20 /$ \\
\hline Fecal & $33 / 72(46 \%)^{\mathrm{a}}$ & $46 / 72(63 \%)^{\mathrm{b}}$ & $46 / 72(63 \%)^{\mathrm{b}}$ & $58 / 7$ \\
\hline Total & $52 / 113(46 \%)$ & $63 / 113(56 \%)$ & $62 / 113(55 \%)$ & $84 / 113(74 \%)$ \\
\hline
\end{tabular}

* It was classified as biofilm-producer the isolate positive in at least one assay performed.

a,b Within a line and column, values with different superscripts are significantly $(P<0.05)$ different regarding the sample source versus the assay employed and assay according the sample source, respectively.
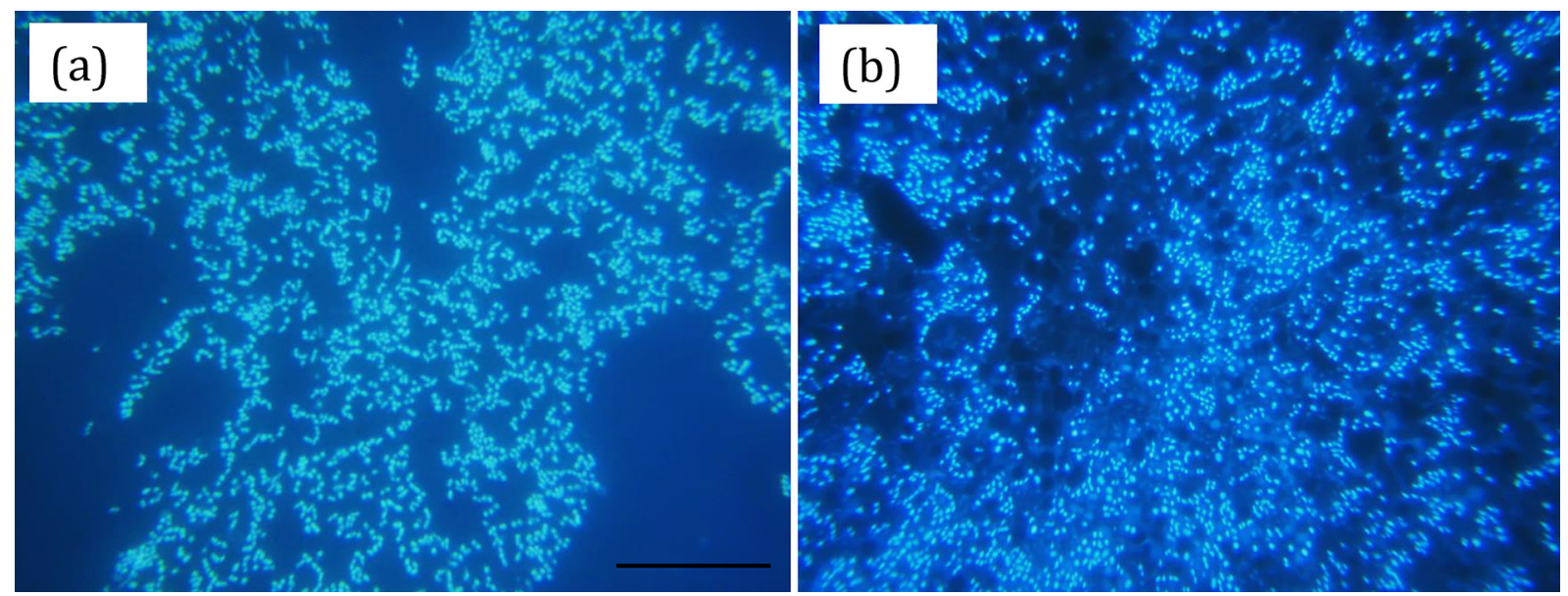

Fig.1. Biofilm formation by Rhodococcus equi isolates. The bacteria were grown on a glass slide during $24 \mathrm{~h}$, stained with DAPI and examined with an epifluorescence microscopy (100x). (a) Aggregate of $R$. equi cells without EPS matrix. (b) Aggregate of $R$. equi cells surrounded by EPS matrix (clouding effect surrounding the bacteria due the biofilm formation). Scale bar $=20 \mu \mathrm{m}$. 
and 55\% (62/113) of R. equi isolates using BC, BCG and EM assay, respectively. There is no statistically significant difference between clinical and fecal samples regarding the biofilm formation, however, we found significant increase in fecal $R$. equi isolates when glucose was added (Table 1). Biofilm positive and negative $R$. equi cells accessed by EM are demonstrated in Figure $1 \mathrm{a}$ and $1 \mathrm{~b}$, respectively.

\section{Correspondence among assays}

The biofilm-positive Rhodococcus equi in at least one of the tests performed were considered biofilm-producer. Therefore, biofilm formation was verified in $74.3 \%$ $(84 / 113)$ of $R$. equi isolates analyzed, with $63.4 \%(26 / 41)$ and $80.5 \%(58 / 72)$ of clinical and fecal isolates, respectively. Eight clinical $R$. equi isolates recovered as biofilm-positive by $\mathrm{BC}$ became biofilm-negative in $\mathrm{BCG}$, and six isolates recovered as biofilm-negative by $\mathrm{BC}$ had a biofilm-positive phenotype in BCG. On the other hand, in fecal isolates, 18 biofilm-negative strains in $\mathrm{BC}$ were observed as biofilm-positive in BCG. All biofilm-positive fecal isolates in BC remained biofilm-positive in BCG.

For clinical isolates, a correlation index of 0.56 was observed among BC, BCG and EM $(P=0.0001)$ using the Spearman analysis. On the other hand, fecal $R$. equi isolates showed an increase in the biofilm-formation frequency when used BCG and EM tests, which had the same sensibility to detect biofilm formation, showing a strong correlation index of $0.52(\mathrm{P}=0.0001)$.

\section{Antimicrobial activity}

Antimicrobial susceptibility testing of planktonic $\boldsymbol{R}$. equi suspensions. We evaluated the in vitro antimicrobial susceptibility of eight planktonic suspensions of $R$. equi (four from clinical samples and four from fecal samples) to AZT, CLAR and ERY. All isolates analyzed were susceptible to AZT and CLAR. To ERY, four isolates showed intermediate susceptibility and four were susceptible. The results may be observed in Table 2 .

Antimicrobial susceptibility testing of $R$. equi in established biofilms. We used the antimicrobials at concentrations at least 4 times their respective MICs to evaluate their effects on established biofilms. At $24 \mathrm{~h}$ incubation
Table 2. Minimal inhibitory concentration of azithromycin, clarithromycin and erythromycin against clinical and fecal Rhodococcus equi isolates

\begin{tabular}{|c|c|c|c|}
\hline \multirow[t]{2}{*}{ Strain $(n=8)$} & \multicolumn{3}{|c|}{$\operatorname{MIC}(\mu \mathrm{g} / \mathrm{mL})$} \\
\hline & Azithromycin & Clarithromycin & Erythromycin \\
\hline R. equi 488/00‡ & $1.0^{\mathrm{a}}$ & $0.25^{\mathrm{a}}$ & $0.5^{\mathrm{a}}$ \\
\hline R. equi $27 / 98 \neq$ & $1.0^{\mathrm{a}}$ & $0.125^{\mathrm{a}}$ & $2.0^{\mathrm{b}}$ \\
\hline R. equi 353/93 & $0.125^{\mathrm{a}}$ & $0.25^{\mathrm{a}}$ & $0.5^{\mathrm{a}}$ \\
\hline R. equi $25 / 03 \ddagger$ & $1.0^{\mathrm{a}}$ & $0.0625^{\mathrm{a}}$ & $1.0^{\mathrm{b}}$ \\
\hline R. equi 490/95 DID $†$ & $1.0^{\mathrm{a}}$ & $0.125^{\mathrm{a}}$ & $1.0^{\mathrm{b}}$ \\
\hline R. equi 490/95 INB $†$ & $0.5^{\mathrm{a}}$ & $0.0625^{\mathrm{a}}$ & $0.5^{\mathrm{a}}$ \\
\hline R. equi 490/95 TRA $†$ & $1.0^{\mathrm{a}}$ & $0.0625^{\mathrm{a}}$ & $2.0^{\mathrm{b}}$ \\
\hline R. equi 490/95 IST $†$ & $0.5^{\mathrm{a}}$ & $0.0625^{\mathrm{a}}$ & $0.5^{\mathrm{a}}$ \\
\hline
\end{tabular}

‡ Clinical sample; † Fecal sample.

a Susceptible; ${ }^{\text {b }}$ Intermediate susceptibility.

$\mathrm{S}: \leq 2 \mu \mathrm{g} / \mathrm{mL}$ (AZM and CLR) and $\leq 0.5 \mu \mathrm{g} / \mathrm{mL}$ (ERY); R: $\geq 8 \mu \mathrm{g} / \mathrm{mL}$ (AZM, CLR and ERY), IS: MIC values between the concentrations mentioned (CLSI, 2008 and 2009).

there was significant $(P<0.05)$ decrease in $R$. equi concentration in presence of AZT, CLAR and ERY. We observed a nearly 3-log order decrease in $R$. equi concentration relative to control levels (untreated cells) (Table 3). However, none of the antimicrobials used were able to eradicate $R$. equi in established biofilms (Table 3).

\section{DISCUSSION}

The biofilm formation by bacterial pathogens of veterinary importance has received relatively little attention (Jacques et al. 2010). According to Kaplan (2010) the microorganisms detached from biofilms have an important role in the bacterial dissemination of environmental reservoirs to human or animal, as well as the microorganism transmission among hosts. It is well known that biofilm provides resistance to antimicrobials and play an important virulence factor in chronic bacterial infections in animals, such as endometritis in horses (Ferris et al. 2014). The ability of Rhodococcus equi to form biofilm can be highly favorable for it survival in the environment as well as in the host. This is the first study evaluating the biofilm formation by $R$. equi with significant number of isolates.

Several conditions can influence the biofilm formation/detection, such as the method employed, nutritional requirements and metabolic pathways (e.g. glucose, iron

Table 3. Azithromycin, clarithromycin and erythromycin activity on Rhodococcus equi established biofilm

\begin{tabular}{|c|c|c|c|c|}
\hline \multirow[t]{2}{*}{ Strain $(n=8)$} & \multicolumn{4}{|c|}{ Mean cell density (CFU/ml) after $24 \mathrm{~h}^{1}$} \\
\hline & Biofilm untreated & Biofilm + AZT & Biofilm + CLAR & Biofilm + ERY \\
\hline R. equi $488 / 00 \ddagger$ & $3.1 \times 10^{8}$ & $5.9 \times 10^{5 *}$ & $1 \times 10^{5 *}$ & $3 \times 10^{5 *}$ \\
\hline R. equi $27 / 98 \neq$ & $1.5 \times 10^{8}$ & $6.9 \times 10^{5 *}$ & $3 \times 10^{5 *}$ & $7.2 \times 10^{5 *}$ \\
\hline R. equi $353 / 93 \ddagger$ & $2.2 \times 10^{8}$ & $7.8 \times 10^{5 *}$ & $2.5 \times 10^{5 *}$ & $3.2 \times 10^{5 *}$ \\
\hline R. equi $25 / 03 \ddagger$ & $1.8 \times 10^{8}$ & $6.8 \times 10^{5 *}$ & $1.1 \times 10^{5 *}$ & $7 \times 10^{5 *}$ \\
\hline R. equi 490/95 DID $\dagger$ & $1.9 \times 10^{8}$ & $4.5 \times 10^{5 *}$ & $7 \times 10^{4 *}$ & $3.3 \times 10^{5 *}$ \\
\hline R. equi 490/95 INB & $1.2 \times 10^{8}$ & $6.7 \times 10^{5 *}$ & $1.1 \times 10^{5 *}$ & $5.5 \times 10^{5 *}$ \\
\hline R. equi 490/95 TRA $\dagger$ & $1.2 \times 10^{8}$ & $2.2 \times 10^{5 *}$ & $8 \times 10^{4 *}$ & $1.1 \times 10^{5 *}$ \\
\hline R. equi 490/95 IST $\dagger$ & $1.9 \times 10^{8}$ & $3.2 \times 10^{5 *}$ & $8.5 \times 10^{5 *}$ & $1.7 \times 10^{5 *}$ \\
\hline
\end{tabular}

‡ Clinical sample; † Fecal sample.

${ }^{1}$ Cell density was determined by enumerating CFU by 10 -fold serial dilutions plated on TSA; the values are the average of duplicate-independent experiments.

*Indicates statistically significant difference from control by one-way ANOVA and Turkey's test $(P<0.05)$. 
and phosphate concentration) (Jacques et al. 2010). Considering this, we aimed verify the $R$. equi biofilm formation using two different methods and one nutritional variable. For isolates from the same source, all approaches showed high concordance $(P=0.0001)$. Thus we classified as biofilm-producer the R. equi isolate positive in at least one of the tests performed. Although some isolates were found biofilm-positive in one method and negative in another, this was not unexpected. Similar findings was observed by Knobloch et al. (2002) studying biofilm formation by clinical and commensal Staphylococcus aureus.

Glucose seems as an important substrate required for biofilm-formation by fecal-isolates of $R$. equi (Table 1). Studies involving several microorganisms also observed an increase in the ability to form biofilm when used glucose medium supplemented (reviewed by Stepanovic et al. 2007). In contrast, the presence of glucose did not influence the biofilm formation by clinical isolates (Table 1). We believe that different regulatory mechanisms or conditions could be active in biofilm expression between pathogenic and environmental R. equi. According to Coelho et al. (2008) the biofilm formation is complex and probably multifactorial, with different substrates and expression autoinducers, especially among isolates from different source.

Among the fecal-isolates of R. equi, 80.5\% (58/72) were classified as biofilm-producers. The protection ensured by the EPS matrix during stress conditions, including exposition to UV radiation (Espeland et al. 2001) and metal toxicity (Teitzel \& Parsek 2003) may be highly advantageous during the saprophytic life of $R$. equi. In this way, Tripathi et al. (2012) showed a mechanism by which the virulence plasmid can move among $R$. equi in the soil. These authors highlight a possible relationship between conjugation and biofilm formation by environmental $R$. equi.

We found 63\% (26/41) of clinical-isolates of $R$. equi as biofilm-producers. Usually, bacterial biofilms are associated with prolonged-treatment infections (Kulka et al. 2012), as well as with its recurrence or persistence (Hall-Stoodley et al. 2004). In general, $R$. equi infection has a long-term antimicrobial therapy, around 4-9 weeks, and, besides, these infections become chronic (Prescott 2004). To the best of our knowledge, there are three studies regarding R. equi biofilm formation that together evaluated only ten isolates, six clinical (associated to chronic infection in humans) (Akhrass et al. 2012, Remuzgo-Martínez et al. 2013) and four from soil (Mart yanov et al. 2014). Akhrass et al. (2012) found three strains positive for biofilm formation, while Remuzgo-Martínez et al. (2013) verified only one.

None isolate analyzed here showed resistant profile to antimicrobials (ATM) tested, as presented in Table 2. To access the susceptibility of $R$. equi in established biofilms it was used $8 \mu \mathrm{g} / \mathrm{mL}$ of each ATM, 8 to $64 \mathrm{xMIC}$ verified for AZT, 32 to $128 \times$ MIC for CLAR and 4 to $8 x M I C$ for ERY. A previous study demonstrated that the average of 4 to 8 times the MIC could eradicate biofilm of Gram-positive bacteria (Raja et al. 2011). In the present study, R. equi in established biofilms were recovered even after exposure to high ATM concentrations, however, CFU amount reduction was statically significant (Table 3). Two studies concerning antimicrobial susceptibility of clinical and environmental $R$. equi producing biofilm were performed by Akhrass et al. (2012) and Mart yanov et al. (2014). The first study found R. equi biofilm reduced completely or partially by antimicrobial solutions. Mart'yanov et al. (2014) found a unexpected pattern, $R$. equi biofilm persistence was observed in the treatments with high AZT concentration (15 to $50 \mu \mathrm{g} /$ $\mathrm{mL}$ ), while at $8 \mu \mathrm{g} / \mathrm{mL}$ the planktonic and biofilm growth were similar.

In the present study, we observed a nearly 3-log order decrease in $R$. equi concentration relative to control levels (untreated cells) (Table 3). Similar results were verified by Ojha et al. (2008) with Mycobacterium tuberculosis biofilm after rifampicin $(50 \mu \mathrm{g} / \mathrm{mL})$ treatment. Although the reduction have been expressive, these authors indicate that subpopulation of cells surviving this treatment were able to replicate following 7 day of exposure. Even exopolysaccharide matrix does not form an impenetrable barrier to the diffusion of antimicrobial agents (Mah \& O'Toole 2001), the observation of tolerant subpopulation may mean an important way of ATMs resistance.

Oggioni et al. (2006) observed that cells from biofilm-producing pneumococcal are more effective in inducing pneumonia than the planktonic cells. In addition, microorganisms growing on EPS matrix are able to resist to the host defenses, i.e., by impairing the phagocytic activity of neutrophils (Yamanaka et al. 2009) - and act as reservoirs for antibiotic resistance genes (Jacques et al. 2010). The influence of biofilm in $R$. equi pneumonia, especially in the cases unresponsive to treatment, may require some special attention.

\section{CONCLUSIONS}

Both clinical and fecal Rhodococcus equi isolates are able to form biofilm according the methods used. Those may represent a quick and reliable methodology to study R. equi biofilm.

Glucose addiction seems to increase the ability of fecal isolates to produce biofilms.

None antimicrobials tested was able to eradicate $R$. equi in biofilm, even at high concentrations.

Our findings indicate that $R$. equi biofilm-producers may be more resistant to the antimicrobials evaluated. Further studies are warranted to test this hypothesis.

Conflict of interest statement.- All authors declare there are no personal conflicts of interests that could inappropriately influence or bias the content of the paper.

Acknowledgements.- The authors acknowledge the financial support from CNPq (Conselho Nacional de Desenvolvimento Científico e Tecnológico), specially for Letícia Trevisan Gressler Master of Science Scholarship (process number: 130023/2012-4) and FAPERGS (Fundação de Amparo à Pesquisa do Estado do Rio Grande do Sul). We thank to Dr. Berta Maria Heinzmann for helpful comments to the manuscript.

\section{REFERENCES}

Agarwal A. \& Jain A. 2013. Glucose \& sodium chloride induced biofilm production \& ica operon in clinical isolates of staphylococci. Indian J. Med. Res. 138(2):262-266. 
Akhrass F.A., Wohoush I.A., Chaftari A.M., Reitzel R., Jiang Y., Ghannoum M., Tarr J., Hachem R. \& Raad I. 2012. Rhodococcus bacteremia in cancer patients is mostly catheter related and associated with biofilm formation. Plos One $7:$ :e32945.

Arlotti M., Zoboli G., Moscatelli G.L., Magnani G., Maserati R., Borghi V., Andreoni M., Libanore M., Bonazzi L. \& Piscina A. 1996. Rhodococcus equi infection in HIV-positive subjects: a retrospective analysis of 24 cases. Scand. J. Infect. Dis. 28:463-467.

CLSI 2008. Performance Standards for Antimicrobial Disk and Dilution Susceptibility Tests for Bacteria Isolated from Animals: approved standard. 3rd ed. Clinical and Laboratory Standards Institute Document M31-A3. Clinical and Laboratory Standards Institute, Wayne, PA.

CLSI 2009. Performance Standards for Antimicrobial Susceptibility Testing; approved standard, 10th ed. Clinical and Laboratory Standards Institute Document M100-S19. Clinical and Laboratory Standards Institute, Wayne, PA.

CLSI 2013. Performance Standards for Antimicrobial Disk and Dilution Susceptibility Tests for Bacteria Isolated from Animals: approved standard. 4th ed. Clinical and Laboratory Standards Institute Document VET01-A4. Clinical and Laboratory Standards Institute, Wayne, PA.

Cerca N., Martins S., Cerca F., Jefferson K.K., Pier G.B., Oliveira R. \& Azeredo J. 2005. Comparative assessment of antibiotic susceptibility of coagulase-negative staphylococci in biofilm versus planktonic culture as assessed by bacterial enumeration or rapid XTT colorimetry. J. Antimicrob. Chemother. 56:331-336.

Coelho L.R., Souza R.R., Ferreira F.A., Guimarães M.A., Ferreira-Carvalho B.T. \& Figueiredo M.A.S. 2008. agr RNAIII divergently regulates glucose-induced biofilm formation in clinical isolates of Staphylococcus aureus. Microbiology 154:3480-3490.

Costerton J.W., Stewart P.S. \& Greenberg E.P. 1999. Bacterial biofilms: a common cause of persistent infections. Science 284:1318-1322.

Cucarella C., Tormo M.A., Ubeda C., Trotonda M.P., Monzon M., Peris C., Amorena B., Lasa I. \& Penades J.R. 2004. Role of biofilm-associated protein Bap in the pathogenesis of bovine Staphylococcus aureus. Infect. Immun. 72:2177-2185.

Donlan R.M. \& Costerton J.W. 2002. Biofilms: survival mechanisms of clinically relevant microorganims. Clin. Microbiol. Rev. 15:167-193.

Espeland E.M. \& Wetzel R.G. 2001. Complexation, stabilization, and UV photolysis of extracellular and surface-bound glucosidase and alkaline phosphatase: implications for biofilm microbiota. Microb. Ecol. 42:572585.

Feazel L.M., Baumgartner L.B., Peterson K.L., Frank D.N., Harris J.K. \& Pace N.R. 2009. Oppotunistic pathogens enriched in showerhead biofilms. Pnas 106:16393-16399.

Fernandes M.C., Takai S., Leite D.S., Pinto J.P.A.N., Brandão P.E., Santarém V.A., Listoni F.J.P., Da Silva A.V. \& Ribeiro M.G. 2013. Identification of pathogens and virulence profile of Rhodococcus equi and Escherichia coli strains obtained from sand of parks. Braz. J. Microbiol. 44:485-492.

Ferris R.A., Wittstock S.M., McCue P.M. \& Borlee B.R. 2014. Evaluation of biofilms in gram-negative bacteria isolated from the equine uterus. J. Equine Vet. Sci. 34:121

Giguère S. \& Prescott J.F. 1997. Clinical manifestations, diagnosis, treatment, and prevention of Rhodococcus equi infections in foals. Vet. Microbiol. 7:313-334.

Giguère S., Lee E., Williams E., Cohen N.D., Chaffin M.K., Halbert N., Martens R.J., Franklin R.P., Clark C.C. \& Slovis N.M. 2010. Determination of the prevalence of antimicrobial resistance to macrolide antimicrobials or rifampin in Rhodococcus equi isolates and treatment outcome in foals infected with antimicrobial-resistant isolates of $R$ equi. J. Am. Vet. Med. Assoc. 237:74-81.

Hal-Stoodley L., Costerton J.W. \& Stoodley P. 2004. Bacterium biofilm: from the natural environmental to infections disease. Nat. Rev. Microbiol. 2:95-108

Jacques M., Aragon V. \& Tremblay Y.D.N. 2010. Biofilm formation in bacterial pathogens of veterinary importance. Anim. Health Res. Rev. 11:97121.
Kaplan J.B. 2010. Biofilm dispersal: mechanisms, clinical implications, and potential therapeutic uses. J. Dent. Res. 89:205-218.

Knobloch J.K.M., Horstkotte M.A., Rohde H. \& Mack D. 2002. Evaluation of different detection methods of biofilm formation in Staphylococcus aureus. Med. Microbiol. Immunol. 191:101-106.

Kulka K., Hatfull G. \& Ojha A.K. 2012. Growth of Mycobacterium tuberculosis biofilms. J. Vis. Exp. 60:e3820.

Lemon K.P., Earl A.M., Vlamakis H.C., Aguilar C. \& Kolter R. 2008. Biofilm development with an emphasis on Bacillus subtilis. Curr. Top. Microbiol. Immunol. 322:1-16.

Letek M., González P., MacArthur I., Rodríguez H., Freeman T.C., Valero-Rello A., Blanco M., Buckley T., Cherevach I., Fahey R., Hapeshi A., Holdstock J., Leadon D., Navas J., Ocampo A., Quail M.A., Sanders M., Scortti M.M., Prescott J.F., Fogarty U., Meijer W.G., Parkhill J., Bentley S.D. \& Vázquez-Boland J.A. 2010. The genome of a pathogenic Rhodococcus: cooptive virulence underpinned by key gene acquisitions. Plos Genet. 6:1001145.

Mah T.F. \& O'Toole G.A. 2001 Mechanisms of biofilm resistance to antimicrobial agents. Trends Microbiol. 9:34-39.

Marques S.C., Rezende J.G.O.S., Alves L.A.F., Silva B.C., Alves E., Abreu L.R. \& Piccoli R.H. 2007. Formation of biofilms by Staphylococcus aureus on stainless steel and glass surfaces and its resistance to some selected chemical sanitizers. Braz. J. Microbiol. 38:538-543.

Mathur T., Singhal S., Khan S., Upadhyay D.J., Fatma T. \& Rattan A. 2006. Detection of biofilm formation among the clinical isolates of staphylococci: an evaluation of three different screening methods. Indian J. Med. Microbiol. 24:9-25.

Merino N., Toledo-Arana A., Vergara-Irigaray M., Valle J., Solano C., Calvo E., Lopez J.A., Foster T.J., Penadés J.R. \& Lasa I. 2009. Protein A-mediated multicellular behavior in Staphylococcus aureus. J. Bacteriol. 191:832843.

Monego F., Maboni F., Krewer C., Vargas A., Costa M. \& Loreto E. 2009. Molecular characterization of Rhodococcus equi from horse-breeding farms by means of multiplex PCR for the vap gene family. Curr. Microbiol. 58:399-403.

Muscatello G., Anderson G.A., Gilkerson J.R. \& Browning G.F. 2006. Associations between the ecology of virulent Rhodococcus equi and the epidemiology of $R$. equi pneumonia on Australian thoroughbred farms. Appl. Environ. Microbiol. 72:6152-6160.

Muscatello G., Leadon D.P., Klayt M., Ocampo-Sosa A., Lewis D.A., Fogarty U., Buckley T., Gilkerson J.R., Meijer W.G. \& Vazquez-Boland J.A. 2007. Rhodococcus equi infection in foals: the science of 'rattles'. Equine Vet. J. 39:470-478.

Oggioni M.R., Trappetti C., Kadiougiu A., Cassone M., Iannelli F., Ricci S., Andrew P.W. \& Pozzi G. 2006. Switch from planktonic to sessile life: a major event in pneumococcal pathogenesis. Mol. Microbiol. 61:11961210.

Ojha A.K., Baughn A.D., Sambandan D., Hsu T., Trivelli X., Guerardel Y., Alahari A., Kremer L., Jacobs W.R. \& Hatfull Jr G.F. 2008. Growth of Mycobacterium tuberculosis biofilms containing free mycolic acids and harbouring drug-tolerant bacteria. Mol. Microbiol. 69(1):164-174.

O’Toole G., Kaplan H.B. \& Kolter R. 2000. Biofilm formation as microbial development. Annu. Rev. Microbiol. 54:49-79.

Prescott J.F. 1991. Rhodococcus equi: an animal and human pathogen. Clin. Microbiol. Rev. 4:20-34.

Prescott J.F. 2004. Rhodococcus equi, p.87-95. In: Prescott C.L., Thoen C.O., Prescott J.F. \& Songer J.G. (Eds), Pathogenesis of Bacterial Infections of Animals. Blackwell Publ., Ames.

Quinn P.J. 1994. Corynebacterium species and Rhodococcus equi, p.137143. In: Quinn P.J., Carter M.E., Markey B.K. \& Carter G.R. (Eds), Clinical Veterinary Microbiology. Wolfe Publ., London.

Raja A.F., Ali F., Khan I.A., Shawl A.S., Arora D.S., Shah B.A. \& Taneja S.C. 2011. Anti-staphylococcal and biofilm inhibitory activities of acetyl11-keto- $\beta$-boswellic acid from Boswellia serrate. BMC Microbiol. 11: $1-9$.

Stepanovic S., Vukovic D., Hola V., Bonaventura G., Djukic S., Irkovic C. \& 
Ruzicka F. 2007. Quantification of biofilm in microtiter plates: overview of testing conditions and practical recommendations for assessment of biofilm production by staphylococci. APMIS 115:891-899.

Takai S., Ohbushi S., Koike K., Tsubaki S., Oishi H. \& Kamada M. 1991. Prevalence of virulent Rhodococcus equi in isolates from soil and feces of horses from horse-breeding farms with and without endemic infections. J. Clin. Microbiol. 29:2887-2889.

Takai S., Fukunaga N., Ochiai S., Sakai T., Sasaki Y. \& Tsubaki S. 1996. Isolation of virulent and intermediately virulent Rhodococcus equi from soil and sand on parks and yards in Japan. J. Vet. Med. Sci. 58:669-672.

Takai S. 1997. Epidemiology of Rhodococcus equi infections: A review. Vet. Microbiol. 56:167-176.
Teitzel G.M. \& Parsek M.R. 2003. Heavy metal resistance of biofilm and planktonic Pseudomonas aeruginosa. Appl. Environ. Microbiol. 69:23132320.

Tripathi V.N., Harding W.C., Willingham-Lane J.M. \& Hondalus M.K. 2012. Conjugal transfer of a virulence plasmid in the opportunistic intracellular actinomycete Rhodococcus equi. J. Bacteriol. 194(24):6790-6801.

Von Bargen K. \& Haas A. 2009. Molecular and infection biology of the horse pathogen Rhodococcus equi. FEMS Microbiol. Rev. 33(5):870-891.

Yamanaka T., Furukawa T., Matsumoto-Mashimo C., Yamane K., Sugimori C., Nambu T., Mori N., Nishikawa H., Walker C.B., Leung K. \& Fukushima H. 2009. Gene expression profile and pathogenicity of biofilm-forming Prevotella intermedia strain 17. BMC Microbiol. 9(11):1-15. 